\title{
Teaching Practices of EFL Teachers and the Enhancement of Creative Thinking Skills among Learners
}

\author{
Thouqan Saleem Yakoub Masadeh \\ (1) https://orcid.org/0000-0001-9911-4830 \\ Department of Curriculum and Instruction, College of Education, Najran University, \\ Najran, Saudi Arabia \\ *e-mail: tmasadeh@yahoo.com
}

\section{Article Information}

Received: March 11, 2021

Accepted: March 29, 2021

Online: May 12, 2021

\section{Keywords}

Creativity, Creative thinking, Creative thinking skills, Creative thinking activities, EFL teachers, EFL learners

\begin{tabular}{l} 
ABSTRACT \\
\hline The development of students' creativity has been a \\
prerequisite for survival in this fast-changing technological \\
age. Therefore, enhancing learners' higher-order thinking \\
skills should be the primary concern of education systems \\
worldwide. The present study aims to survey EFL teachers' \\
knowledge about creative thinking and their activities to \\
enhance creative thinking skills. It also aims to understand \\
EFL teachers' perceptions about the importance of creative \\
thinking activities in promoting EFL learners' creativity. \\
Moreover, it aims to check if there are significant differences \\
between participants' perceptions due to teaching experience \\
and stage. Fifty-six teachers took part in the present study by \\
responding to a questionnaire developed to achieve the aims. \\
Results revealed EFL teachers' lack of knowledge of creative \\
thinking skills. Nevertheless, they showed that they "Often" \\
practice creative thinking activities in the classroom. Results \\
also indicated that these activities were perceived as \\
"Important" to enhance EFL learners' creative thinking skills.
\end{tabular}

\section{INTRODUCTION}

We, nowadays, live in a changeable world where rapid development and advances in science and technology have nearly affected all aspects of life. Jobs, which are the main source of income and consequently the primary source of comfort and happiness, have become competitive. In order to get a job that fulfills the demands of such comfortable life, an individual has to have new characteristics because those conventional ones are insufficient to be accepted in today's workplace. Employees, workers, teachers, artists, students, businesspersons have to be creative in their jobs; otherwise, they will not compete and survive for a long time in their places. People who are capable of generating original and valuable ideas will soon replace them. Thus, to remain competitive, individuals, nations, and organizations must think differently and make connections between seemingly unrelated things (Ritter, Gu, Crijns, \& Biekens, 2020). Thinking differently means that the person has to be creative in his thinking. He has to use his ability to categorize and manipulate objects (Ward, Finke, \& Smith, 1995). Very early in this century, Adair (2007) argued that the importance of creative thinking needs no emphasis. The person will have a competitive advantage once he improves his ability to innovate and come up with new ideas.

Creativity is often defined as anything that goes beyond what is already known. It is the exploration and development of new ideas or ways of thinking. It is small or large successful steps into a new thought process or area of knowledge (Torrance, 1977). As a conception, creativity is a mental phenomenon that results from the application of ordinary cognitive processes such as working memory 
and categorizing and manipulating objects (Ward, Smith \& Vaid, 1997). Mental processes are the essence of creative endeavor. Creative cognition begins by looking at an ancient subject, like dreams, for instance. Intuition and insight are then taken up from a contemporary cognitive perspective, and the importance of using prior knowledge in the incremental view of creative problem solving (Ward, Finke \& Smith, 1995). Creativity involves divergent thinking that includes the beginning of beautiful ideas, creating new connections, expanding the limits of knowledge, and splitting old ideas (Rotaru, 2020).

Creative thinking skills are one of the capabilities required to solve various problems ( Runisah, Herman, \& Dahlan, 2016). Newell, Shaw, \& Simon, very early in the 1960s, stated that problem-solving is a creative activity once thinking is unconventional, i.e., the thinking person can accept or reject previously accepted ideas and leads to novelty and value. Moreover, creative thinking needs high motivation, persistence and takes place over a considerable period or at a high intensity (McFadzean, 2000). Unlike fixed inborn traits, creativity can be taught and developed (Kleibeuker, De Dreu \& Crone, 2016). Nevertheless, classroom activities and teaching materials do not represent much attention to introducing and practicing cognitive strategies proven to foster creative thinking skills ( $\underline{\mathrm{Ritter}, \mathrm{Gu}}$, Crijns, \& Biekens, 2020). Therefore, education should aim to create human beings capable of doing new things, not just use and consume things and knowledge created by ancestors. Creative thinking behaviors grow up among individuals and their physical growth from the first day they come to life. It is seen once they try to make sense of the things in their community that does not imply simple explanations and once they begin to create stories to explain phenomena that are nonsensical to them (Newton \& Newton, 2010). To develop students' creativity, we need creative instructors who can actualize all abilities to educate, train and guide students in line with the expected aims (Craft, Hall, \& Costello, 2014). However, teachers' encouragement or discouragement of this kind of exploration can highly enhance or not enhance this creative process (Roy, 2012). Teachers who foster an appreciation for creativity and innovation can provide students with the cutting edge in their future endeavors.

Moreover, creative instructors are to find new strategies to develop the potentials of students. They must try to create a comfortable and pleasing learning environment for students to make them able to explore their abilities (Rahman, 2017). They should not only look at creativity in the learners' writing and art and not as its line of thinking and processing information (Bolden, Harries, \& Newton, 2010). Hence, analysis of the teachers' beliefs about specific activities that might enhance their student's creative thinking skills inside the classroom can lead to understanding how teachers can be empowered to incorporate such skills into their classes.

The way teachers perceive creativity can shed light on how they actualize classroom environments rich in creative thinking and practice (Mullet, Willerson, Lamb, \& Kettler, 2016). Therefore, the present study aims to determine what EFL teachers utilize most in their classes to foster their creative thinking skills and creativity. The following questions guided the present study:

1. To what extent are EFL teachers knowledgeable of creative thinking skills?

2. What are the activities EFL teachers mostly use in their classes to enhance their learners' creativity and creative thinking skills?

3. What activities do EFL teachers perceive as highly important to enhance their learners' creativity and creative thinking skills?

4. Do activities teachers practice inside their classes to promote their learners' creativity and creative thinking skills vary due to the teaching stage and experience?

\section{Fostering Creativity of Learners}

Knowledge creation and innovation in the era of the knowledge economy are significant. Today's era is witnessing the rise of many new educational policies, more tensions, and more dilemmas. Thus, a more profound understanding of learning and the provision of students with various skills and knowledge make the need for creative thinking more demanded than ever. Creative teaching, which needs creative teachers, can help students meet their educational needs (Reilly, Lilly, Bramwell, \& Kronish, 2011). Besides teaching language, mathematics, and science, teachers should teach creative language, creative mathematics, and creative science (Soh, 2017). To create a creative classroom environment, teachers need to have a specific school culture, pedagogical content knowledge about creativity, and pedagogical practices that foster creativity (Tan, Lee, Ponnusamy, Koh, \& Tan, 2016). Certain factors can, on the opposite inhibit teachers and students from being creative, like the fixed class 
schedule, constant monitoring of learning, emphasis on high-stakes examination, and the vague understanding of creativity concept (Simonton, 2004). However, facilitative pedagogical practices such as designing novel learning tasks to stimulate students' creativity, planning for the learning experience that is flexible and self-directed, setting a mutual respect atmosphere, open dialogue, and collaborative activities can, for sure, foster creativity ( Craft \& Jeffrey, 2013). However, other dilemmas like conflicts in policy and practice; tensions in meeting the subject matter requirements, designing learning tasks to foster student creativity; the fear of curricular chaos; and the call for subject-content-based curriculum to teach for creativity can impede teachers' understanding of this concept and their attitudes toward it (Troman, Jeffrey, \& Raggl, 2007). Stressing the importance of teachers' creativity is not new. Researchers since the middle of the 1990s have argued that teachers of a humanistic philosophical orientation have developed their creative competencies and implemented specific creative methods and techniques in their classrooms. Besides, they were more effective in enhancing students' creative abilities than teachers, who followed traditional teaching approaches (Esquivel, 1995).

In order to develop creativity in a child, it is necessary to create opportunities and design activities for action, for creative problem solving, and for discovering new things. For instance, Fisher (2006:6) argues that teachers should allow students specific opportunities to develop their creative thinking. They, for instance, should allow them to:

1. Use their imagination.

2. Generate questions, ideas, and outcomes.

3. Experiment with alternatives.

4. Be original.

5. Expand on what they know or say.

6. Exercise their judgment.

Długosz (2015; 2908-9), on the other part, claims that to develop learners' creativity, teachers should:

1. Allow learners to try new things, to make mistakes, and to reach the essence of the problem on their own instead of suggesting ready-made solutions.

2. Ask learners unconventional questions and meanwhile encourage them to ask questions that show their curiosity about the world around them.

3. Encourage them to read what is around them and stimulate their imagination.

4. Inspire and support them to play creatively and reward them by appreciating their efforts.

5. Praise them when doing something difficult, even if it is unnecessary.

6. Stimulate their vision, hearing, touch, and taste senses during the lesson.

Thammineni (2012:66), in turn, provided a set of activities, which he described as innovative and encouraged teachers to practice them inside the classroom:

1. Task-based activities

2. Contests

3. Language games

4. Video or movie sharing

5. Media literacy

6. Translation

7. Computer-Assisted Language Learning (CALL) programs.

Creativity represents the ability to imagine or invent something original. Using such an ability, learners can create ideas, find solutions, search thoughts, and create pieces of work by using changes, distinct combinations, and replications of existing ideas. Therefore, teachers' constant and positive feedback empowers them to build their self-esteem as they learn to accept parent's and teachers' criticism in the same way they accept praise. Enhancing children's social skills by sharing new ideas, original thoughts, and novel opportunities might be the most effective creativity activities (Rotaru, 2020). In teaching English to students of other languages, Arabic, for example, it is challenging to adopt any educational context. Teachers often struggle to design enjoyable and fruitful activities to engage students in creativity. Therefore, they have to try different strategies that demand a greater level of creativity. One way to do so is to see creativity as a spark for students' motivation and making language

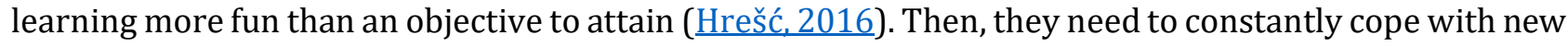


situations, tasks, and challenges that explore their creativity. They should firmly believe that they might be the only source for EFL learners' knowledge in the classroom environment, and so their role could be very decisive in promoting creativity (Fitriah \& Elke, 2016).

Developing learners' creativity is an essential part of the pedagogical process. Like their peers of other school subjects, EFL Teachers are advocated to be more creative while asking questions, making connections, looking at things in new ways, exploring ideas, and reflecting on what they have learned and taught (Jesson, 2012). When coping with learners, they show their values and pedagogical beliefs about creativity, which can serve as a foundation for their decision-making. Nevertheless, research on EFL teachers' creativity is still not paid the attention it deserves. Most of the research has focused on creative students' issues and the process and concept of creativity in general. Throughout all the definitions provided by different studies, it can be argued that creativity is associated with several attributes of which EFL teachers and learners should be aware. These attributes involve imagination, divergence, intellectuality, lack of conventionality, originality, and flexibility (Hana \& Hacène, 2017). Therefore, the present study explores teachers' views regarding creativity in EFL classrooms within Saudi public education.

\section{METHODS}

The present study was quantitative, and so the descriptive analytical approach was used to analyze the collected data.

\section{Participants}

A total of (56) EFL teachers were selected randomly from all public schools of the General Directorate of Education in Najran, Saudi Arabia. They were all teaching English to male students only as co-education in Saudi Arabia is not allowed. Therefore, all of them were requested to reply to a questionnaire prepared to achieve the study aims. Besides, they were graduated from different Saudi universities with at least a Bachelor's degree in the English Language. Demographic information of these teachers is presented in Table 1.

Table 1. Demographic information of participant teachers

\begin{tabular}{lcc}
\hline Teaching Stage & Teaching Experience & $\mathbf{N}$ \\
\hline Elementary Stage & One year - five years & 3 \\
& Six years - Ten years & 6 \\
& More than ten years & 3 \\
Intermediate Stage & Total & $\mathbf{1 2}$ \\
& One year - five years & 13 \\
& Six years - Ten years & 6 \\
Secondary Stage & More than ten years & 4 \\
& Total & $\mathbf{2 3}$ \\
& One year - five years & 10 \\
& Six years - Ten years & 5 \\
\hline Total & More than ten years & 6 \\
\hline
\end{tabular}

\section{Instrument}

To achieve the study's aims, a four-section questionnaire was prepared according to the activities that EFL teachers should implement inside the classroom to foster their learners' creativity. The first 
section of the questionnaire addressed participant teachers' demographic information, i.e., teaching experience and stage. The second section consisted of (15) items and targeted EFL teacher's knowledge about creative thinking (Hana \& Hacène, 2017). The third section containing (22) activities was assigned to understand to what extent participants implement activities that are assumed to foster creativity among EFL learners. Statements were arranged in a five-point Likert scale ranging from $1=$ never $(0 \%)$, $2=$ seldom $(10 \%), 3=$ sometimes $(50 \%), 4=$ often $(75 \%)$, and $5=$ usually $(95 \%)$. Therefore, items whose mean scores range between (1.00-1.80) express sporadic activity practice, (1.81-2.60) show that the activity is seldom practiced, (2.61-3.40) mean that the activity is sometimes practiced, (3.41-4.20) reveal that the activity is often practiced, and (4.21-5.00) indicate that the activity is usually practiced.

The fourth section consists of the same (22) activities in the first part, but aimed to investigate EFL teachers' perceptions of the importance of these activities in enhancing EFL learners' creativity. Again, statements were presented in a five-point Likert scale ranging from $1=$ unimportant, $2=$ of little importance, $3=$ moderately essential, $4=$ important, and $5=$ very important. Therefore, mean scores ranging between (1.00-1.80) express no importance, (1.81-2.60) show little importance, (2.61-3.40) represent moderate importance, (3.41-4.20) reveal high level of importance, and (4.21-5.00) reflect very high level of importance. It is worth mentioning that the third and fourth sections were previously used by Roy (2012) and Haxhihyseni (2015).

\section{Data analysis}

SPSS software program was used for further analysis of data. First, mean scores and standard deviations of participants' responses were calculated. Moreover, ANOVA was applied to determine if significant differences between participants' perceptions due to the teaching experience and stage exist.

\section{RESULTS}

\section{Knowledge of EFL teachers about Creative Thinking}

To explore EFL teachers' knowledge about creative thinking, they were offered fifteen creative thinking sub-skills and were requested to distinguish the skills that, in their opinion, are related to creative thinking. Unfortunately, analysis of collected data revealed that about $50 \%$ of participants could not identify all the creative thinking skills. That is, their knowledge about creative thinking sub-skills was not satisfactory. Therefore, it can be argued that participant teachers have a pretty confusing concept of creativity and have uncertain knowledge about its characteristics.

Table 2. Sum and mean for EFL teachers' knowledge about creative thinking

\begin{tabular}{lcc}
\hline Creative thinking subskills & Sum & Mean \\
\hline Brainstorming/ Generating new ideas & 46 & 82.1 \\
The ability to produce various ideas or solutions about the same thing or & 33 & 58.9 \\
problem & & \\
Relating knowledge from several areas & 24 & 42.8 \\
Thinking outside the box & 19 & 33.9 \\
Seeking new ways of looking at a problem & 19 & 33.9 \\
Using old ideas to create new ones & 18 & 32.1 \\
Flexibility & 18 & 32.1 \\
Fluency and elaboration of ideas/Divergent Thinking & 18 & 32.1 \\
Solving problems by imagination & 15 & 26.8 \\
Evaluating and interpreting an idea & 13 & 23.2 \\
Drawing conclusions & 13 & 23.2
\end{tabular}


Producing a solution that is both novel and suitable

Generalization from given facts

Making unusual associations among unrelated things

Findings in Table 2 demonstrate that the means of six subskills out of the fifteen items were in the range of $17.9 \%-26.8 \%$. These skills were "Solving problems by imagination ( $M=26.8)$; Evaluating and interpreting an idea ( $M=23.2)$; Concluding ( $M=23.2)$; Producing a solution that is both novel and suitable $(M=21.4)$; Generalization from given facts $(M=19.6)$; Making unusual associations among unrelated things $(M=17.9)$, and Curiosity and risk-taking $(M=17.9) "$. The only subskill distinguished by forty-six teachers $(\mathrm{M}=82.1)$ was "Brainstorming/ generating new ideas."

\section{Activities of EFL Teachers to Enhance Learners' Creative Thinking Skills}

To identify what EFL teachers mostly use in their classes to enhance their learners' creativity and creative thinking skills, a group of (22) activities were presented to them and then were requested to determine their practice degree of each activity. Mean scores and standard deviations of teachers' responses are presented in table 3. Analysis of the gathered data shows that respondents' overall practice degree of creative thinking activities was $(M=3.84)$ indicating that they often enhance students' creativity and creative thinking skills. Table 3 shows respondents' degree of the practice of each creative thinking activity.

Table 3. Respondent teachers' practice degree of creative thinking activities

\begin{tabular}{lcccc}
\hline Creative thinking activities & M & SD & $\begin{array}{c}\text { Practice } \\
\text { degree }\end{array}$ & Rank \\
\hline Friendly competition takes place in the classroom. & 4.48 & 0.69 & Usually & $1^{\text {st }}$ \\
I respect the ideas of all students in my classroom. & 4.45 & 0.74 & Usually & $2^{\text {nd }}$ \\
$\begin{array}{l}\text { I carry out activities that require students to create a solution } \\
\text { or idea. }\end{array}$ & 4.30 & 0.85 & Usually & $3^{\text {rd }}$ \\
$\begin{array}{l}\text { I involve students in a brainstorming process before starting } \\
\text { a new project or concept. }\end{array}$ & 4.29 & 0.87 & Usually & $4^{\text {th }}$ \\
I encourage students to feel comfortable when asking & 4.21 & 0.91 & Usually & $5^{\text {th }}$ \\
questions and making mistakes. & & & & \\
$\begin{array}{l}\text { I allow students to choose their projects for demonstrating } \\
\text { their knowledge. }\end{array}$ & 4.21 & 1.00 & Usually & $6^{\text {th }}$ \\
I teach multiple ways of finding a problem. & 4.18 & 0.79 & Often & $7^{\text {th }}$ \\
$\begin{array}{l}\text { I praise neatness and consistency. } \\
\text { I relate the content material in class to real-world } \\
\text { experiences. }\end{array}$ & 4.18 & 1.13 & Often & $8^{\text {th }}$
\end{tabular}


I show examples of someone else's work before beginning a new project.

I use brainteasers, word problems, and puzzles in the classroom.

I focus on classroom topics that students already understand.

I use visualization as a technique in the classroom.

I encourage independent learning.

I provide ample feedback along with grades when grading student work.

I keep my art materials (markers, glue, crayons, and more.) locked up not available to students.

I involve multiple senses in lessons.

I use ungraded assignments to allow students to practice new material.

I provide activities that allow students to think backward to solve a problem.

I evaluate students' work based on the correct answer, not the correct process.

When I ask questions, I look for the correct answer.

My students spend the majority of the day seated at their desks.

$4.07 \quad 0.89 \quad$ Often $\quad 10^{\text {th }}$

$4.05 \quad 1.03 \quad$ Often $\quad 11^{\text {th }}$

$3.89 \quad 1.04 \quad$ Often $\quad 12^{\text {th }}$

$3.890 .89 \quad$ Often $\quad 13^{\text {th }}$

$3.89 \quad 1.09 \quad$ Often $\quad 14^{\text {th }}$

$3.80 \quad 1.00 \quad$ Often $\quad 15^{\text {th }}$

$3.73 \quad 1.26 \quad$ Often $\quad 16^{\text {th }}$

$3.70 \quad 0.99 \quad$ Often $\quad 17^{\text {th }}$

$0.97 \quad$ Often

$18^{\text {th }}$

Often

$19^{\text {th }}$

$3.09 \quad 1.20 \quad$ Sometimes $20^{\text {th }}$

$2.50 \quad 1.35 \quad$ Seldom $\quad 21^{\text {st }}$

$2.14 \quad 1.34 \quad$ Seldom $22^{\text {nd }}$

\section{Total mean score}

Often

Results in Table 3 show that, among all creative thinking activities, teachers usually practice holding friendly competition ( $M=4.48)$, respecting the ideas of all students $(M=4.45)$, and carrying out activities that require students to create a solution or an idea $(M=4.30)$. Furthermore, they usually involve students in a brainstorming process before starting a new project or concept $(M=4.29)$, encourage students to feel comfortable when asking questions and making mistakes $(\mathrm{M}=4.21)$, and allow students to choose their projects for demonstrating their knowledge (M=4.21). Nevertheless, they sometimes practice evaluating students' work based on the correct answer, not on the correct process $(M=3.09)$, while they seldom look for the correct answers when they ask questions $(M=2.50)$ and spend the majority of the class time leaving students seated in their desks (M=2.14).

\section{Perceptions of EFL Teachers about the Importance of Creative Thinking Activities to Promote Learners' Creativity}

To identify EFL teachers' perceptions about the importance of specific activities in promoting their learners' creativity, a group of (22) activities were presented to them and then asked to determine the importance of each activity. Data analysis showed that the presented activities were seen, in general, 
as important $(M=3.97)$. Mean scores and standard deviations of teachers' responses to the importance of each activity are presented in table 4 .

Table 4. Importance degree of creative thinking activities

\begin{tabular}{|c|c|c|c|c|}
\hline Creative thinking activities & $\mathbf{M}$ & SD & $\begin{array}{l}\text { Importance } \\
\text { degree }\end{array}$ & Rank \\
\hline $\begin{array}{l}\text { Respecting and rewarding the ideas of others, including } \\
\text { students. }\end{array}$ & 4.55 & 0.50 & V. important & $1^{\text {st }}$ \\
\hline Teaching multiple ways to solve a problem & 4.52 & 0.57 & V. important & $2^{\text {nd }}$ \\
\hline Friendly competition & 4.45 & 0.50 & V. important & $3^{\text {rd }}$ \\
\hline $\begin{array}{l}\text { Providing multiple options for students to demonstrate } \\
\text { understanding of the material }\end{array}$ & 4.45 & 0.66 & V. important & $4^{\text {th }}$ \\
\hline Using brainteasers, word problems, and puzzles & 4.39 & 0.73 & V. important & $5^{\text {th }}$ \\
\hline Brainstorming before beginning a project & 4.34 & 0.72 & V. important & $6^{\text {th }}$ \\
\hline Relating content material to real-world experiences & 4.27 & 0.90 & V. important & 7 th \\
\hline Using a visualization technique & 4.25 & 0.67 & V. important & $8^{\text {th }}$ \\
\hline Asking questions and making mistakes & 4.23 & 0.93 & V. important & $9^{\text {th }}$ \\
\hline Creating new ideas and solutions to problems & 4.21 & 0.85 & Important & 10th \\
\hline Using multiple senses in a lesson & 4.18 & 0.90 & Important & $11^{\text {th }}$ \\
\hline $\begin{array}{l}\text { Focusing on topics students have previously learned or } \\
\text { understood }\end{array}$ & 4.13 & 0.92 & Important & $12^{\text {th }}$ \\
\hline $\begin{array}{l}\text { Showing examples of previous work before starting a } \\
\text { project }\end{array}$ & 4.05 & 0.94 & Important & $13^{\text {th }}$ \\
\hline Praising neatness and consistency & 4.05 & 1.14 & Important & $14^{\text {th }}$ \\
\hline Encouraging independent learning & 3.95 & 1.18 & Important & $15^{\text {th }}$ \\
\hline Providing ample feedback along with a grade & 3.84 & 1.01 & Important & $16^{\text {th }}$ \\
\hline Providing ungraded practice problems & 3.77 & 0.93 & Important & $17^{\text {th }}$ \\
\hline Keeping art materials available at the student's level & 3.73 & 1.20 & Important & $18^{\text {th }}$ \\
\hline $\begin{array}{l}\text { Using activities that make students think backward to find } \\
\text { the solution }\end{array}$ & 3.73 & 1.18 & Important & $19^{\text {th }}$ \\
\hline
\end{tabular}


Basing grades on the answer, not the process

Asking questions with one specific answer in mind

Spending time doing seatwork
1.50
Moderately

$20^{\text {th }}$ important

Moderately important

$21^{\text {st }}$
Little importance

Results in Table 4 show that, among the presented creative thinking activities, teachers believe that respecting and rewarding the ideas of others $(\mathrm{M}=4.55)$, teaching students multiple ways to solve a problem ( $M=4.52)$, and conducting friendly competitions $(M=4.45)$ were the most important activities by which students' creativity and creative thinking skills can be enhanced. Furthermore, they think that providing students with multiple options to demonstrate understanding of the learning material $(M=4.45)$, using brainteasers, word problems, and puzzles $(M=4.39)$, in addition to brainstorming before beginning a project $(\mathrm{M}=4.34)$, were also of great importance in promoting students' creativity. Nevertheless, their responses showed that evaluating students based on grades on the answer, not on the process $(M=3.04)$, and asking questions with one specific answer in mind $(M=2.71)$ were of moderate importance. Meanwhile, doing seatwork $(\mathrm{M}=2.59)$ was seen as of little importance in developing students' creative thinking.

\section{Effect of Teaching Stage on the Practice Degree of Creative Thinking Activities}

In order to distinguish the role of the teaching stage on creative thinking activities' practice degree, ANOVA was used. Table 5 shows the results.

Table 5. ANOVA for the effect of teaching stage on creative thinking activities' practice degree

\begin{tabular}{lccccc} 
Teaching stage & Sum of squares & DF & Mean square & F. & Sig. \\
\cline { 1 - 3 } Between groups & 00.091 & 02 & 0.045 & 0.225 & 0.799 \\
Within groups & 10.698 & 53 & 0.202 & & \\
\cline { 1 - 2 } Total & 10.798 & 55 & & & \\
\hline
\end{tabular}

Statistics in table 5 reveal no statistically significant differences between respondents' perceptions according to the importance of the creative thinking activities due to the teaching stage, whether they are elementary, intermediate, or secondary teachers.

\section{Effect of Teaching Experience on the Practice Degree of Creative Thinking Activities}

In order to distinguish the role of the teaching experience, participants were teaching in, on their practice degree of the creative thinking activities ANOVA was used. Table 6 shows the results.

Table 6. ANOVA for the effect of teaching experience on creative thinking activities' practice degree

\begin{tabular}{lccccc}
\hline Teaching experience & Sum of squares & DF & Mean square & F & Sig. \\
\cline { 1 - 3 } Between groups & 00.272 & 02 & 0.136 & 0.685 & 0.508 \\
Within groups & 10.517 & 53 & 0.198 & & \\
\cline { 1 - 3 } Total & 10.789 & 55 & & & \\
\cline { 1 - 3 } & \multicolumn{2}{l}{} & & &
\end{tabular}


Statistics in table 6 reveal no statistically significant differences between teachers' perceptions according to the importance of the creative thinking activities due to the teaching experience from 1-5 years, 6-10 years, or above ten years.

\section{DISCUSSION}

The first part of the present study aimed to determine the level of respondent EFL teachers' knowledge about creativity. Analysis of gathered data revealed that participants lack a clear understanding of creativity. Their knowledge was too poor, too. The only skill that half of them could distinguish as one main component of creativity was brainstorming and generating new ideas. One interesting reason behind this mal knowledge and unfamiliarity, as discussed by Bereczkia \& Kárpáti (2018), might be teachers' training and experience in teaching creativity; personal creativity; and overall professional competency, which might affect positively or negatively their conceptions of creativity. Lorimer (2018) presents other factors like teachers' culture and bias towards students of favorable characteristics, and high intellectual abilities may not help them recognize creativity potentials. Furthermore, teachers' understanding of innovation cognitive strategies, the distinction of the most conducive social and academic environment, and their perceptions of testing, in most cases, inhibit creative practices in the classroom. Kasmaienezhadfard, Talebloo, Roustae, \& Pourrajab (2015) stressed the importance of making teachers aware of the importance of creativity in classrooms. Creative activities must be institutionalized and allocated adequate time and space, while teaching practices and techniques must be connected with creative outcomes.

The second part of the present study tried to assess how often EFL teachers practice teaching activities to promote their creativity. Data analysis showed that mean scores of respondents' responses ranged from usually to seldom, and the average mean score of their practice degree of all activities was $(M=3.84)$, indicating that, in general, they do not always or usually think of doing so. Organizing competitions, respecting all students' ideas, carrying out activities that require students to create a solution or idea, and involving students in a brainstorming process before starting a new project or concept were the most practiced activities. This defect in EFL teachers' performance is because teachers are trained to consume knowledge, not produce creative ideas and solutions, so they begin to face problems. Therefore, training and developing new teaching content that can enhance creative performance can bridge the gap (Ritter \& Mostert, 2017). Therefore, teachers need to understand how to promote their creativity in authentic contexts. It is challenging to induce creativity by telling teachers to be creative, but they should be provided with some essential supervision on how to be creative and consequently teach creatively and train students to think creatively (Niu \& Liu, 2009). The findings of this study emphasize the results of Al-Qahtani (2016) concerning the little effort EFL teachers make to foster creativity in their teaching practices. Thus, textbook designers and EFL supervisors, and teachers must be familiarized with the importance and applications of creativity. Hui, Chow, Chan, Chui, \& Sam (2015) interpret EFL teachers' failure to implement creative activities in the classroom by the lack of confidence and suitable training programs. Moreover, teachers themselves are not skilled enough and their perceptions of creativity because they seem ill-equipped to foster their learners' creativity.

The third aim of the present study was to determine the importance of carrying out creative thinking activities in classrooms. Mean scores of EFL teachers' responses extended from very important to moderately important. The average mean score of all activities was $(M=3.97)$, revealing that it was essential to implement creative thinking to improve EFL learners' creativity. Nine activities were reported very important to be implemented in the class compared to ten less critical activities, i.e., necessary. The other three activities were revealed to be of moderate and minor importance. Respecting and rewarding the ideas of students $(\mathrm{M}=4.55)$ and teaching multiple ways to solve a problem $(\mathrm{M}=4.52)$ were the essential activities from the viewpoint of respondents. While asking questions with one specific answer in mind $(M=2.71)$ and spending time doing seatwork $(M=2.59)$ were perceived as the least important activities. Two main factors affect the creation of a creative teaching environment. The first is the teachers' level of awareness of their roles in enhancing learners' creativity. The second is their ability to integrate knowledge in a new way to make different combinations or add new ideas to previously acquired knowledge to create something unusual (Mariani \& Ismail, 2015).

Furthermore, teachers' persistence, willingness to develop, acceptance of new experiences, motivation, and sense of humor were found as decisive factors influencing creative teaching (Horng, 
Hong, ChanLin, Chang, \& Chu, 2005). In addition, the school environment, including other teachers, the principal, other school students, and school administration policies, affect teachers' creativity (Palaniappan, 2009). One more exciting source of teachers' creativity is their perceptions and concepts of creativity, which cause them difficulties when assessing their creativity and the creativity of the activities they try to implement in classrooms (Morais. \& Azevedo, 2011).

Concerning the effect of the teaching stage and experience on respondents' viewpoints, results showed no significant differences due to these two variables. Such finding can be because all participant teachers graduated from Saudi universities where higher education levels are nearly the same. Moreover, they were all subjected to similar courses offered to them during their academic study because they all acquired approximate knowledge and abilities. Therefore, the differences between them were slight. Besides, they were all teachers at public schools administered by the same regulations leading to similar teaching environments. This result confirms previous studies concluding that teachers' grade level, subject, experience, and age do not affect their perception of creativity characteristics (Kettler, Lamb, Willerson, \& Mullet, 2018). In brief, investigating EFL teachers' conceptions about creative thinking activities inside classrooms showed that most of them look at themselves as creative teachers though they could not distinguish what activities are related to creativity. Hence, participant EFL teachers' responses help identify a need for a teacher training about creativity and raise suggestions for this work.

\section{CONCLUSION}

Human beings are endowed with many attributes among which is creativity. Activating this attribute can enhance our mentality and cognition. It can arouse our curiosity and make us more optimistic as we think critically of our surroundings. Creative teachers can activate their students' latent creativity and empower them to look at problems facing as interesting puzzles not as challenges. Creative thinking is a key competency for entrepreneurial activities and long life learning. Literature and scientific research show that creativity has no limits and no universal prescription can be proposed to inspire teachers' creativity, but have shown that there are many hindrances that can impede this inspiration process such school environment, principal and students. Findings of the present study have revealed the respondents' teachers' need for training to familiarize them with creativity notion and activities that may enhance it. Thus, the findings stress the importance to train Saudi EFL teachers on asking unusual questions, creating and presenting imaginative ideas, creating an ethos where ideas have value, and making combinations of existing ideas. Teaching strategies and activities that nurture students' competencies should be included in EFL school curriculum. Furthermore, developing students' creativity and creative thinking should be a broad aim of EFL teaching at schools.

\section{Funding and Conflicts of Interest:}

The authors declare that there is no funding and conflicts of interest for this research.

\section{REFERENCES}

Adair, J. (2007). The Art of Creative Thinking: How to Be Innovative and Develop Great Ideas, London and Philadelphia, Kogan Page Limited

Al-Qahtani, A. A. (2016). Do Saudi EFL Teachers Promote Creativity in Their Classrooms? English Language Teaching, 9 (4). DOI:10.5539/elt.v9n4p11

Bereczkia, E. O. \& Kárpáti, A. (2018). Teachers' Beliefs about Creativity and its Nurture: A Systematic Review of the Recent Research Literature, Educational Research Review, 23, 25-56.

https://doi-org.sdl.idm.oclc.org/10.1016/j.edurev.2017.10.003

Bolden, D. S., Harries, T. V., \& Newton, D. P. (2009), Pre-Service Primary Teachers' Conceptions of Creativity in Mathematics, Educational Studies in Mathematics, 73, 143-157. https://link.springer.com/article/10.1007/s10649-009-9207-z

Craft, A., Hall, E., \& Costello, R. (2014). Passion: Engine of Creative Teaching in an English University? Thinking Skills and Creativity, 13, 91-105. https://doi.org/10.1016/j.tsc.2014.03.003 
Craft, A., Jeffrey, B. (2013). Creativity and Performativity in Teaching and Learning: Tensions, Dilemmas, Constraints, Accommodations and Synthesis, Br. J. Educ. Stud., 34, 577-584. https://doi.org/10.1080/01411920802223842

Długosz, M. W. (2015). Stimulating the Development of Creativity and Passion in Children and Teenagers in Family and School Environment - Inhibitors and Opportunities to Overcome them, Procedia - Social and Behavioral Sciences, 174, 2905 - 2911. DOI: http://doi.org/10.1016/j.sbspro.2015.01.1027

Esquivel, G. B. (1995). Teacher Behaviors that Foster Creativity, Educational Psychology Review, 7 (2). https://link.springer.com/article/10.1007/BF02212493

Fisher, R. (2006). Expanding Minds: Developing Creative Thinking in Young Learners, CATS: Children and Teenagers: The IATEFL Young Learners SIG Publication. https://yltsig.iatefl.org/wpcontent/uploads/2016/10/2006-spring.pdf

Fitriah, F. \& Elke, S. (2016): Teachers' Beliefs about Creativity in EFL Higher Education: Voices from Indonesia, Monash University, Conference Contribution. https://doi.org/10.4225/03/583b9e80080c8

Hana \& Hacène, H. (2017). Creativity in the EFL Classroom: Exploring Teachers' Knowledge and Perceptions, Arab World English Journal (AWEJ), 8 (4). https://dx.doi.org/10.24093/awej/vol8no4.24

Haxhihyseni, S. (2015). Creative Thinking - Perception of Teachers in Relation to its Importance, European Journal of Social Sciences, 2 (2). DOI: http://dx.doi.org/10.26417/ejser.v3i2.p83-89

Horng, J. S., Hong, J. C., ChanLin, L. J., Chang, S. H., \& Chu, H. C. (2005). Creative Teachers and Creative Teaching Strategies, International Journal of Consumer Studies, 29 (4), 352-358. http://www.mifras.org/know/wp-content/uploads/2014/06/Creative-teachers-andcreative-teaching-strategies.pdf

Hrešć, T. (2016). Ways of Promoting Creativity in EFL Classroom, Graduation Thesis, Department of English, University of Zagreb. http://darhiv.ffzg.unizg.hr/id/eprint/6532/1/Hresc,\%20Tihana.pdf

Hui, A., Chow, B., Chan, A., Chui, B., \& Sam, C. (2015). Creativity in Hong Kong Classrooms: Transition from a Seriously Formal Pedagogy to Informally Playful Learning, International Journal of Primary, Elementary and Early Years Education, 43(4), 393-403

Jesson, J. (2012). Developing Creativity in the Primary School, New York: Open University Press, McGraw Hill. https://www.mheducation.co.uk/developing-creativity-in-the-primary-school9780335244638-emea-group

Kasmaienezhadfard, S., Talebloo, B., Roustae, R., \& Pourrajab, M. (2015). Students' Learning through Teaching Creativity: Teachers' Perception, Journal of Educational, Health and Community Psychology, 4 (1). https://media.neliti.com/media/publications/24806-EN-studentslearning-through-teaching-creativity-teachers-perception.pdf

Kettler, T., Lamb, K. N., Willerson, A., \& Mullet, D. R. (2018). Teachers' Perceptions of Creativity in the Classroom, Creativity Research Journal, 30 (2), 164-171, https://doi.org/10.1080/10400419.2018.1446503

Kleibeuker, S. W., De Dreu. C. K. \& Crone E. A. (2016). Creativity Development in Adolescence: Insight from Behavior, Brain, and Training Studies. New directions for child and adolescent development. 151, 73-84. https://doi.org/10.1002/cad.20148

Lorimer, K. (2018). Creativity in our Curriculum? Teachers' Perceptions, Project, Christian Heritage College. DOI: $10.13140 / R G .2 .2 .22058 .93124$ 
Mariani, A., \& Ismail, Z. (2015). The Elements of Teachers' Competency for Creative Teaching in Mathematics. International Education Studies, 8 (13), 93-97.

http://dx.doi.org/10.5539/ies.v8n13p93

McFadzean, E. (2000), Techniques to Enhance Creative Thinking, Team Performance Management, 6 (3/4), 62-72. https://doi.org/10.1108/13527590010731989

Morais, M. F. \& Azevedo, I. (2011). What is a Creative Teacher and What is a Creative Pupil? Perceptions of Teachers, Procedia Social and Behavioral Sciences, 12, 330-33. https://doi.org/10.1016/j.sbspro.2011.02.042

Mullet, D. R., Willerson, A., Lamb, K. N., \& Kettler, T. (2016). Examining Teacher Perceptions of Creativity: A Systematic Review of the Literature, Thinking Skills and Creativity, 21, 9-30. https://doi.org/10.1016/j.tsc.2016.05.001

Newton, L. D. \& Newton, D. P. (2010). What Teachers See as Creative Incidents in Elementary Science Lessons. International Journal of Science Education, 32 (15). 1989-2005. http://dx.doi.org/10.1080/09500690903233249

Niu, W. \& Liu, D. (2009). Enhancing Creativity: A Comparison between Effects of an Indicative Instruction "to Be Creative" and a more Elaborate Heuristic Instruction on Chinese Student Creativity, Psychology of Aesthetics, Creativity, and the Arts, 3 (2), 93-98. DOI: $10.1037 / \mathrm{a} 0013660$

Palaniappan, A. K. (2009). Creative Teaching and its Assessment, Paper presented at the $12^{\text {th }}$ UNESCOAPEID International Conference with the theme "Quality Innovations for Teaching and Learning" on 24 - 26 March 2009 held at Impact Exhibition and Convention Center, Bangkok, Thailand. https://core.ac.uk/download/pdf/162007177.pdf

Rahman, M. H. (2017). Using Discovery Learning to Encourage Creative Thinking, International Journal of Social Sciences \& Educational Studies, 4 (2). https://doi.org/10.23918/IJSSES.V4I2SIP98

Reilly, R. C., Lilly, F., Bramwell, G., \& Kronish, N. (2011). A Synthesis of Research Concerning Creative Teachers in a Canadian Context. Teaching and Teacher Education, 27, 533-542. http://dx.doi.org/10.1016/j.tate.2010.10.007

Ritter, S. M. \& Mostert, N. (2016). Enhancement of Creative Thinking Skills Using a Cognitive-Based Creativity Training, Journal of Cognitive Enhancement volume 1, 243-253. DOI: https://doi.org/10.1007/s41465-016-0002-3

Ritter, S. M. \& Mostert, N. (2017). Enhancement of Creative Thinking Skills Using a Cognitive-Based Creativity Training, Journal of Cognitive Enhancement 1, 243-253. DOI: 10.1007/s41465016-0002-3

Ritter, S. M., Gu, X., Crijns, M., \& Biekens, P. (2020). Fostering Students' Creative Thinking Skills by Means of a One-Year Creativity Training Program, PLoS One, 15(3). https://doi.org/10.1371/journal.pone.0229773

Rotaru, R.E. (2020). Stimulating Primary School Children's Creativity. Revista Romaneasca Pentru Educatie Multidimensionala, 12(4), 431-439. https://doi.org/10.18662/rrem/12.4/355

Roy, J. (2012). Elementary Teachers' Perceptions of their Teaching Practices to Foster Creative Thinking in Their Students, Curriculum and Instruction Undergraduate Honors Theses. 1. https://core.ac.uk/download/pdf/72840081.pdf

Runisah, Herman, T. \& Dahlan, J. (2016). The Enhancement of Students' Creative Thinking Skills in Mathematics through the 5E Learning Cycle with Metacognitive Technique, International Journal of Education and Research, 4 (7). https://www.ijern.com/journal/2016/July2016/28.pdf 
Simonton, D.K. (2004). Creativity in Science: Chance, Logic, Genius, and Zeitgeist; Cambridge University Press: Oxford, UK.

Soh, K. (2017). Fostering Student Creativity through Teacher Behaviors, Thinking Skills and Creativity, 23, 58-66. https://doi.org/10.1016/j.tsc.2016.11.002

Tan, L. S., Lee, S. S., Ponnusamy, L. D., Koh, E. R., \& Tan, C. K. (2016). Fostering Creativity in the Classroom for High Ability Students: Context Does Matter, Educ. Sci., 6, (36). https://doi.org/10.3390/EDUCSCI6040036

Thammineni, H. B. (2012). Creativity, the Crux of English Language Teaching and Learning. IUP Journal of Soft Skills, 6 (1), 65-71. https://papers.ssrn.com/sol3/papers.cfm?abstract id=2152956

Torrance, E. P. (1977). Creativity in the classroom, Washington, DC: National Education Association.

Troman, G.; Jeffrey, B.; Raggl, A. (2007). Creativity and Performativity Policies in Primary School Cultures, J. Educ. Policy, 22, 549-572. https://doi.org/10.1080/02680930701541741

Ward T. B., Smith, S. M. \& Vaid, J. (1997). Conceptual Structures and Processes in Creative thought, in Creative Thought: An investigation of conceptual structures and processes. Washington DC: American Psychological Association. 1997.

Ward, T. B., Finke, R. A., Smith, S. M. (1995). Creativity and the Mind, New York Plenum Press. 